\title{
Corporate Social Responsibility and Tax Avoidance in Nigeria
}

\author{
Timothy $\mathrm{Oboh}^{1 *} \quad$ Omoregie Nosa ${ }^{2}$ \\ 1.Department of Accounting, Faculty of Management Sciences, University of Benin, \\ PMB 1154, Benin City, Nigeria \\ 2.Faculty of Management Sciences, Ambrose Alli University Ekpoma, P.O.BOX 14 Edo State, Nigeria
}

\begin{abstract}
This study focused on the impact of corporate social responsibility (CSR) on tax avoidance in Nigeria. In a bid to achieve this, data was collected from the annual reports and accounts of banks quoted on the floor of the Nigerian stock exchange. From the analysis carried out it was observed that return on asset was found to have a positive relationship with tax avoidance. CSR was found to have a positive relationship with tax avoidance. It was also found to be non-statistically significant when tested at $5 \%$ level of significance. The last variable which is firm size was found to have a negative relationship with tax avoidance. It was however not found to be statistically significant when tested at $5 \%$ level of significance. It was therefore recommended that if an organisation wants to avoid tax it must first of all utilize it resources to the best capacity. Corporate social responsibility is a major means of avoiding taxes due to the fact that the cost involved in engaging in corporate social responsibility is very high so therefore it is lessening the tax burden that is due to an organisation. Also, the size of firm is not a major determinant of the level of tax avoidance.
\end{abstract}

Keywords: Tax avoidance, Corporate social responsibility (CSR), Firm size

DOI: $10.7176 / \mathrm{RJFA} / 12-8-04$

Publication date: April $30^{\text {th }} 2021$

\section{Introduction}

Corporate social responsibility and tax avoidance are important topics in research and management literature (Hoi, Wu \& Zhang, 2013). However, there has been little attention paid to the relationship between corporate social responsibility and tax avoidance in Nigeria. Although research has been carried out independently on each of this fields. The importance of socially responsible firms has increased tremendously. It is a current trend that many firms are associated with socially responsible activities and are increasingly producing brochures and reports to show their conduct (Sikka, 2010). However, some of these firms have shown irresponsible behaviour such as tax avoidance and evasion which is intended to reduce tax liabilities. Whereas they claim to be a public concern organization and increasingly devoting into social and environmental needs (Nadiah, Wan Nur, Syakirah, Mastora, Rohayu, \& Rozainum, 2017)."

Tax evasion and tax avoidance are sometimes used interchangeably but there is a major difference between them. Tax evasion involves using illegal practices to escape from taxation. It is an attempt to reduce tax owing or reduce refundable credits by illegal means such as making false statement about income or destroying records. Tax avoidance in contrast takes place within the legal context of the tax system that involves individuals or firms taking advantage of tax code and exploiting loopholes that is, engaging in activities that are legal but run counter to the purpose of the tax laws. It can be seen as simply restructuring tax affairs legally in turn paying less than the actual tax.

In the year 2009, US treasury had estimated that more than 345 billion loss for each year as a result of various tax avoidance and evasion schemes. The government reported estimates during the period 1998-2005 that nearly $66 \%$ domestic and $68 \%$ of large foreign companies did not pay any federal corporate taxes having generated gross revenue of billions (Sikka, 2010). Most of the companies had given excuses by disclosing their social responsibility behaviour, which they deemed as though they had been paying a fair share of corporate taxes. However, in reality many of these entities had used corporate social responsibility (CSR) as a ploy to cover up their tax aggressive behaviours in an endeavour to gain public trust and confidence (Nadiah, Wan Nur Syakirah, Mastora, Rohayu \& Rozainum, 2017). The payment of taxes ensure financing of public goods and non-payment of corporate taxes leads to a reduction in corporate tax revenue and produces a significant and potentially irrecoverable loss to the society as a whole and this can be considered socially irresponsible (Freise, Link, \& Mayer, 2008). The behaviour of these entities has made the public and society question their sincerity towards their interest and needs when they are actually engaged in large scale tax avoidance.

The after-effects of corporate taxes are a motivating factor for many corporate decisions, such as when managers direct their actions to minimise corporate taxes through tax avoidance practices and this is becoming an increasingly common feature of the corporate landscape all over the world (Desai \& Dharmapala, 2006). The payment of corporate taxes ensures the financing of public goods (Freise, Link \& Mayer, 2008). Consequently, tax avoidance practices might have a negative effect on the society (Friedman, 2003; Landloff, 2006). Besides when a firm is considered to carryout tax avoidance, it is generally not deemed to be paying its fair share of 
corporate tax to the government to ensure the financing of public goods (Freedman, 2003) which leads to loss in the revenue that can be used in improving the quality of life of people.

There are few studies on the perspective of the relationship between corporate social responsibility and tax avoidance in Nigeria and there is a limited work on analysing the relationship between CSR and tax avoidance as well. However, Mgbame, Chijoke, Yekini \& Yekini, (2017) investigated the effect of corporate social responsibility (CSR) performance on tax aggressiveness. They found a significant relationship between CSR performance and tax aggressiveness. They concluded that firms are more or less likely to engage in tax aggressiveness depending on their CSR standpoints and other corporate characteristics.

Hence, this research aims to analyse the relationship between corporate social responsibility and tax avoidance practices amongst listed firms in Nigeria in conjunction with the influence of firm characteristics of profitability and firm size on tax avoidance

In line with this, the broad objective of the study is to examine the relationship between corporate social responsibility (CSR) and tax avoidance in Nigeria. Other specific objectives are to: Determine the relationship between corporate social responsibility and tax avoidance; Examine the effect of firm's profitability on the level of tax avoidance practices in Nigeria; and Determine effect of firm's size on the level of tax avoidance practices in Nigeria.

The study covered companies listed on the Nigerian stock exchange from 2014 to 2018 . Relevant data were generated from audited financial reports for the period. The choice of this period is hinged on the availability of financial statements and the increase in CSR awareness during the period.

\section{Literature Review}

2.1 Concept of Tax Avoidance

Tax avoidance may simply be seen as the reduction or minimization of a taxpayer tax liability by carefully arranging their affairs in such ways to take advantage of loop holes in the tax law provisions. It is the intentional act of a taxpayer to pay less than what he ought to pay to the tax authority. Alm and Martinez-Vazquez (2001) noted that, tax avoidance is a legal reduction in tax liabilities by practices that take full advantage of the tax code, such as income splitting, postponement of taxes and tax arbitrage across incomes that face different treatments. Tax avoidance arises in a situation where the taxpayer arranges his or her financial affairs in a way that ensures the payment of the least possible amount of tax without infringing the legal rules. It is a term used to highlight the various tools which have been adopted with the aim of saving tax and thus sheltering the taxpayer's income from greater liability that would have been otherwise incurred (Kiabel, 2001). An example of tax avoidance is strategic tax planning where financial affairs are arranged in such order to minimise tax liabilities by either using tax deductions or taking advantage of credits or it could be seen as a technique which taxpayers minimises or escape tax liability. The taxpayer seeks to take full advantage of all exemptions, deduction, concessions, rebates, allowances and other tax reliefs or benefit permitted by law.

Tax avoidance was analysed by the economists Brooks and Head (1997) as "having the primary focus clearly on contrived and artificial schemes, which do not change the substantive character of an activity or transaction but may serve nevertheless to bring the activity within some tax-exempt or more tax-favoured legal category.

\subsection{Concept of Corporate social Responsibility (CSR)}

Over the past few decades CSR has been become strategically important for companies wishing to become good corporate citizens which is presently considered as an essential quality for a firm wishing to thrive and achieve its goals. (Vonwil \& Wreshnoik, 2009). Corporate social responsibility is a form of self-regulation which incorporates issues of "sustainability, sustainable development, environmental management, business ethics, philanthropy and community investment, workers' rights, welfare, human rights, corporate governance and legal compliance and animal rights" (Dillard \& Murray, 2013). Bowen (1953) introduced the modern concept of CSR in his book "social responsibility of the businessman" as the "obligation of businessmen to pursue desirable policies from the perspective of society's goals and values, and make decisions or conduct business within the context of them

According to (Abigail \& Donald, 2000) Corporate social responsibility is often referred to as corporate conscience, corporate citizenship, social performance or suitable responsible business and is some worth related to an action taken by a corporation to adopt a certain standard of self-regulation that a corporation cannot otherwise be forced into, nor does it produce any direct gain by doing. Although there are various opinions regarding CSR and they can be summed up broadly as the activities that are conducted by businesses to satisfy societal values and goals, which go beyond profit making.

The UK institute of directors (2002) hold that CSR is going beyond the legal requirements which organizations are expected to abide to in order to manage the impact their business has on the society, community and environment. In particular this means how organisations interact with their employees, 
customers, suppliers and the community in which they operate as well as the magnitude to which they attempt to protect the environment. Snider, snider, Hill and Martin (2003) argued that corporate social responsibility denotes the obligation of business organisation to use its resources in a way that can benefit the society and all other stakeholders. Stakeholders include those who are considered 'primary' that is, shareholders and investors, customers, employees, suppliers, governments who provide infrastructure and whose laws and regulation must be obeyed, communities in which a firm operates and even the natural environment. Firm survival is predicted on meeting the needs and expectations of primary stakeholders as these stakeholders supply critical resources, place something of value at risk in the firm, or otherwise have sufficient power to affect its performance (Clarkson, 1995). Whereas 'secondary' stakeholders include actors who engaged in transactions with the firm such as the media and are not usually regarded as being essential to a firm's survival. This is in line with definition given by European Union (2002) that defines corporate social responsibility as a concept where organisations incorporate social and environmental concerns in operations of their business and their fundamental interactions of their business with all the constituencies on a voluntary basis.

According to Caroll (1979), CSR is composed of four components namely economic, legal, ethical and philanthropic responsibilities, based on these four components a firm should strive to make profit and meet consumption needs, fulfil economic mission within a legal framework while complying with all laws (Carroll 1979). Ethical responsible firms have an obligation to abide by moral rules defining appropriate behaviour in society, the last responsibility refers to businesses that are not required by law but are not mandated but are expected by stakeholders as demonstration of good citizenship for example, investing in local social enterprise or providing training to employees.

Hoi, Wu and Zhang (2013) views CSR as "shared beliefs within the organisation about the right course of actions that take into account the economic, social and environmental and other externalized company's activities. Although authors agree that the aim of cooperate social responsibility is to contribute to the betterment, some authors also noted that trying to good such not over shadow the purpose of any company that is to maximise the wealth of shareholders. In this regard, Mardsen (2001) stated that a socially responsible firm such aim to be profitable while also contributing to the community's wellbeing. He viewed social responsibility as the real awareness of the consequences of a firm's operation on the society rather than an act of philanthropy.

\subsection{Corporate Social Responsibility and Tax Avoidance}

Park (2017) examined the relationship between Corporate social responsibility (CSR) activities and tax avoidance using residual book tax difference (BTD) using a sample of 1,148 publicly listed Korean firms on Korean stock exchange (KSE) and found that firms with higher CSR activities are less likely to avoid tax regardless of which proxy of tax avoidance is used.

Mgbame et al. (2017) investigated the effect of CSR performance on tax aggressiveness of listed firms in Nigeria using a sample of 50 companies for the period of 2007-2013. The findings revealed that there is a negative relationship between CSR performance and tax aggressiveness in Nigeria which implies that the higher the level of CSR performance the lower the extent of tax aggressiveness. Khan, Yousaf, Khan and Yasir (2014) analysed the relationship between CSR and tax avoidance and tried to accomplish whether business organisations which engage in tax avoidance practices consider themselves as a socially responsible business. Based on their examination they found that business not conducting CSR are more likely to avoid tax and tend to be more aggressive than others who do. Similarly, Lanis and Richardson (2012) examined the association between corporate social responsibility (CSR) and corporate tax aggressiveness based on 408 publicly listed Australian corporations for the year 2008-2009. The results showed a negative and statistically significant association between CSR disclosures and tax aggressiveness, the higher the level of CSR disclosure of a corporations the lower the level of tax aggressiveness.

\subsection{Firm Profitability and Tax Avoidance}

Zhu et al. (2019) examined whether corporate tax avoidance of a firm increases in value or profitability taking data from the annual reports and financial statements of firm listed on Ghana Stock Exchange (GSE). They employed a standard ordinary least square regression and tested hypothesis using SPSS statistical tools they found a negative relationship between tax avoidance measure (ETR) and the measure of profitability (ROA). A low ETR is an indication of a higher corporate tax avoidance with a firm, which implies corporate tax avoidance in fact does translate to profitability and value.

Rani, Susetyo and Faudah (2018) investigated effects of corporate characteristics on tax avoidance, using proxies of profitability, leverage and size. The study selected 49 manufacturing companies listed on the Indonesian stock exchange of the period of 2012-2016 as samples were selected by using the cluster random sampling technique. The result showed that profitability has a significant effect on tax avoidance. The negative relationship between profitability and tax avoidance indicates that the higher the level of profitability the smaller the value of ETR will be which indicates that tax avoidance measures in the company increases. 
Masanwaty (2019) carried out a research to determine to determine the effect of profitability and size of companies listed on the Indonesian stock exchange. The result showed that profitability has a dominant influence on the occurrence of indications of tax avoidance in manufacturing companies listed on the Indonesian stock exchange. This is in line with the result of Mgbame et al. (2017) which revealed that firms not performing well may be more tax aggressive thus there is a negative relationship between financial performance and tax aggressiveness.

\subsection{Firm Size and Tax Avoidance}

Yuniarwati, Ardana, Dewi and Tarumanagara (2017) examined the influence of frim size on tax avoidance and found that firm size has no influence on tax avoidance. They concluded that firm size has no influence on increasing tax avoidance, which is because the taxes are a corporate liability that must be met without exceptions. Large firm or small firm will always be a concern for the tax authorities in terms of fulfilment of tax obligations. However, Octavaniana, Titisari and Chomsatu (2018) found a contradictory result. They carried out research on the effect of firm size on tax avoidance and found that firm size has an effect on tax avoidance that there are a large number of firms who will be committing tax avoidance, and large firms will be more motivated to avoid tax since they bear burden of more taxes. This is in line with Putri (2017) where a significant influence of firm size on tax avoidance was found, there is a positive relationship and every increase in company size will increase tax avoidance and vice versa. The larger the company the higher the possibility of tax evasion."

Rani, Susetyo, and Faudah (2018) carried research on 49 manufacturing companies listed on the Indonesian stock exchange for the period of 2012-2016 and samples were selected using cluster random sampling technique. The result showed that firm size has a significant effect on tax avoidance that is, the greater the size the tax avoidance measures in the company increases. Mgbame et al. (2017) found a significant relationship between firm size and tax aggressiveness and that depending on the method of tax aggressiveness, the firm size may affect tax aggressiveness positively or negatively. The evidence was mixed.

\section{Methodology}

This section develops and explains the data and research methods used to test the research hypothesis. This section describes the data collection and research methodology relevant to the research objectives and association hypothesis investigating the impact of corporate social responsibility on tax avoidance in Nigeria. First, this section presents an overview of the research design, target population, data collection approach, time period, measurement of variables and finally data analysis.

\subsection{Research Design}

For this study, causal research design was used. This research design was used to describe the statistical association between the variables taking into account the fact that there has been an a prior manifestation of the relationship among the variables.

\subsection{Population of the Study}

The population of this study covered all quoted on the floor of the Nigerian stock exchange from 20132018.This study was based on a census of all the banks quoted on the floor of the Nigeria stock exchange.

\subsection{Data collection method}

This study used company's annual reports (secondary data) that were mainly gathered from Nigeria stock exchange market to collect data on hypothesis variables. Cooper \& Schindler (2003) further explain that secondary data is a useful quantitative technique for evaluating historical or contemporary confidential or public records, reports, government documents or opinions.

\subsection{Model Specification and analysis}

This study has four variables, three independent variables and one dependent variable. The dependent variable is tax avoidance and the independent variables are corporate social responsibility, firm profitability and firm size. The model below is specified for this study.

ETRt $=\alpha 0+\beta 1$ CSRit $+\beta 2$ ROA it $+\beta 3$ Fsizw it $+\varepsilon$ it

Where:

$\mathrm{ETR}=$ Effective tax rate

$\mathrm{CSR}=$ Corporate social responsibility

ROS $=$ Return on asset

Fsize $=$ Firm size 


\subsection{Definition and Measurement of Variables}

1. Effective tax rate which is the dependent variable is measured using has total tax expenses divided by the earnings before income tax

2. Return on asset which is a measure for performance is measured as profit after tax divided by total asset.

3. Firm size which measured as the log of total asset.

\section{Data Presentation and Analysis}

This section dwells on the presentation, analysis and interpretation of the data collected for this research work. It forms the basis for drawing conclusion and recommendation about the estimating parameters.

A quantitative analysis of the models specified in the previous chapter is examined empirically. The preliminary analysis of the data where first conducted (descriptive analysis) and next the regression assumption analysis test for variables. Thereafter, the regression analysis test was conducted using the panel regression analysis which encompasses the fixed effect and random effect model. Model selection for the variables where carried out using the Hausman Test to ascertain which model is more suitable for drawing conclusion about the study. The regression was carried out taking in to account the impact of corporate social responsibility on tax avoidance in Nigeria.

Table 1. Descriptive Statistics

\begin{tabular}{|l|l|l|l|l|}
\hline & TA & ROA & ETR & FSIZE \\
\hline Mean & 2.923611 & 0.053611 & 0.345895 & 7.619738 \\
\hline Median & 2.833330 & 0.010000 & 0.115602 & 7.245611 \\
\hline Maximum & 5.666670 & 1.170000 & 7.970000 & 12.32769 \\
\hline Minimum & 1.833330 & 0.000000 & 0.000000 & 4.877377 \\
\hline Std. Dev. & 0.684582 & 0.146944 & 1.213223 & 1.768723 \\
\hline Skewness & 1.082080 & 6.367857 & 5.658699 & 0.480407 \\
\hline Kurtosis & 5.616524 & 47.82991 & 33.78834 & 2.652400 \\
\hline Jarque-Bera & 34.58936 & 6515.758 & 3228.016 & 3.131969 \\
\hline Probability & 0.000000 & 0.000000 & 0.000000 & 0.208882 \\
\hline
\end{tabular}

Source: Researcher's compilation,2019

From the result of the descriptive statistics carried out, it was observed that tax avoidance was found to have a mean value of 2.92 with a standard deviation of 0.68 and a jarque Bera value of 34.5 with an associated probability value of 0.00 therefore indicating the absence of an outlier in the data set. Return on asset was found to have a mean value of 0.05 , the standard deviation value measuring the spread of the distribution stood at 0.14 while the jarque bera statistics measuring the normality of the distribution was found to have a probability value which stood at a value of 0.00 which was less than the probability value of 0.05 therefore indicating that the variables are normally distributed. Tax avoidance which was measured using effective tax rate was found to have a value of 0.34 the standard deviation measuring the spread of the distribution stood at a value of 1.21 while the Jarque Bera which measures the normality of the distribution stood at a probability value of 0.00 . Firm size was found to have a mean value of 7.6 the standard deviation measuring the spread of the distribution stood at a value of 1.76 while the Jarque bera statistics which accounts for the normality of the distribution stood at a value of 0.20 . This was the only variable that was not found to be normally distributed when tested at $5 \%$ level of significance. 
Table 2. Regression Result

Dependent Variable: TA

Method: Panel Least Squares

Date: 12/18/19 Time: 04:06

Sample (adjusted): 20142018

Periods included: 5

Cross-sections included: 144

Total panel (unbalanced) observations: 57

\begin{tabular}{lllll}
\hline \hline Variable & Coefficient & Std. Error & t-Statistic & Prob. \\
\hline \hline ROA & -0.381604 & 0.174685 & -2.184524 & 0.0348 \\
CSR & 0.002131 & 0.002154 & 0.988986 & 0.3286 \\
FSIZE & -0.007673 & 0.020740 & -0.369935 & 0.7134 \\
C & 1.123986 & 0.163331 & 6.881629 & 0.0000 \\
\hline \hline \multicolumn{5}{l}{ Effects Specification } \\
\\
\hline \hline Cross-section fixed (dummy variables) & & \\
\hline \hline R-squared & 0.495169 & Mean dependent var & 1.048070 \\
Adjusted R-squared & 0.293237 & S.D. dependent var & 0.212825 \\
S.E. of regression & 0.178921 & Akaike info criterion & -0.361429 \\
Sum squared resid & 1.280504 & Schwarz criterion & 0.247902 \\
Log likelihood & 27.30073 & Hannan-Quinn criter. & -0.124622 \\
F-statistic & 2.452155 & Durbin-Watson stat & 2.307383 \\
Prob(F-statistic) & 0.010934 & & \\
\hline \hline
\end{tabular}

Source: Eviews, 8.0

\subsection{Signs, coefficients and significance of variables}

From the regression result it was observed that return on asset was found to have a positive relationship with tax avoidance. It was also found to be statistically significant when tested at 5\% level of significance.

CSR was found to have a positive relationship with tax avoidance. It was also found to be non-statistically significant when tested at 5\% level of significance. The last variable which is firm size was found to have a negative relationship with tax avoidance. It was however not found to be statistically significant when tested at $5 \%$ level of significance.

\subsection{Coefficient of Determination and F-Statistics}

Furthermore, an examination of the coefficient of determination depicted as R2 it was found to have a value of 0.49 . This therefore implies that on the average the model account for $49 \%$ of the systematic variation exhibited by the dependent variable. While the remaining $52 \%$ left on accounted for is been captured by the stochastic error term.

The F-statistic measuring the overall significance of the model stood at a value of 2.4 therefore indicating that the model is jointly statistically significant. The Durbin Watson statistics measuring the presence of autocorrelation was found to have a value of 2.3 this therefore implies that on the average the presence of autocorrelation does not exist in this model.

\section{Summary, Conclusion and Recommendations}

The objective of the study was to examine the relationship between corporate social responsibility and tax avoidance in Nigeria. In achieving this, listed banks in the Nigeria Stock Exchange were randomly selected and analysed using multiple regressions to check for the existence of relationships between the dependent and explanatory variables.

The chapter concludes on the findings of the study and highlights salient policy recommendations and recommendations for future studies.

\subsection{Summary of Findings}

Based on the above result the following entails the finding of this work

1. From the result above it was observed that return on asset was found to have a positive relationship with tax 
avoidance.

2. CSR was found to have a positive relationship with tax avoidance. It was also found to be non-statistically significant when tested at $5 \%$ level of significance

3. The last variable which is firm size was found to have a negative relationship with tax avoidance. It was however not found to be statistically significant when tested at $5 \%$ level of significance.

\subsection{Conclusion}

Tax avoidance arises in a situation where the taxpayer arranges his or her financial affairs in a way that ensures the payment of the least possible amount of tax without infringing the legal rules. It is a term used to highlight the various tools which have been adopted with the aim of saving tax and thus sheltering the taxpayer's income from greater liability that would have been otherwise incurred (Kiabel, 2001). An example of tax avoidance is strategic tax planning where financial affairs are arranged in such order to minimise tax liabilities by either using tax deductions or taking advantage of credits or it could be seen as a technique which taxpayers minimises or escape tax liability. The taxpayer seeks to take full advantage of all exemptions, deduction, concessions, rebates, allowances and other tax reliefs or benefit permitted by law.

Tax avoidance was analysed by the economists Brooks and Head (1997) as "having the primary focus clearly on contrived and artificial schemes, which do not change the substantive character of an activity or transaction but may serve nevertheless to bring the activity within some tax-exempt or more tax-favoured legal category

\subsection{Recommendation}

1. Return on asset was found to have a positive relationship with tax avoidance.

It is therefore recommended that if an organisation wants to avoid tax it must first of all utilize it resources to the best capacity.

2. CSR was found to have a positive relationship with tax avoidance. It is therefore recommended corporate social responsibility is a major means of avoiding taxes due to the fact that the cost involved in engaging in corporate social responsibility is very high so therefore it is lessening the tax burden that is due to an organisation

3. Firm size was found to have a negative relationship with tax avoidance. It is therefore recommended that the size of firm is not a major determinant of the level of tax avoidance.

\subsection{Recommendation for Further Studies}

1. The time frame and sample size could be increased in order to cover a longer time frame and a more representative sample size in order to enhance the quality of the results.

2. More variables of a technical nature that impinge directly on tax avoidance measurement could also be introduced into the model for more robustness.

\section{References}

Abigail, M., \& Donald, S. (2000). Corporate Social Responsibility And Financial Performance Correlation Or Misspecification. Strategic Management Journal, 603-605.

Alm, J., \& Martinez-Vazquez, J. (2001). Societal Institutions And Tax Evasion In Developing And Transitional Countries. A Paper Prepared For Public Finance In Developing And Transition Countries: A Conference In Honour Of Richard Bird International Studies Program Andrew Young School Of Policy Studies, Georgia University

Bowen, H .R. (1953) Social Responsibilities Of The Business Man. New York, Harper.

Brooks, M., \& Head, J. (1997). Tax Avoidance And The Rule Of Law. 6,181-200.

Caroll, A. B., (1979). A Three Dimensional Conceptual Model Of Corporate Performance. Academy Of Management Review Vol 4, No.4, 497-505.

Clarkson, M.B. (1995). A Stakeholder Framework For Analysing And Evaluating Corporate Social Performance. Academy Of Management Review, 20(1),92-177.

Desai, M.A., \& Dharmapala. D. (2006). Corporate Tax Avoidance And High Powered Incentives. Journal Of Financial Economics, Elsevier.79(1), 145-179.

Dillard, J., \& Murray, A. (2013). Deciphering The Domain Of Corporate Social Responsibility. Corporate Social Europen Union (2002). Corporate Social Responsibility: A Business Contribution To Sustainable Development. Freedman, J. (2003). Tax And Corporate Responsibility. Tax Journal, 695(2), 1-4.

Freise, A., Link, S., \& Mayer, S. (2008). Taxation And Corporate Governance- The State Of Art In: Scheon W. (Ed). Tax And Corporate Governance Springer-Verlag Berlin Heidelberg.

Friedman, J. (2003). Tax And Corporate Social Responsibility. J.695(2) 1-4 Gelb. D, Fraser J.A. (2001). Corporate Social Responsibility And Financial Disclosures: An Alternative Explanation For Increased 
Disclosures, J. Business Ethics 33(1): 1-13

Hoi, C., Wu. Q., Zhang, H. (2013). Is Corporate Social Responsibility Associated With Tax Avoidance? Evidence From Irresponsible Activities. Account. Rev.88(6): 2025-2059.

Khan, M., Yousaf, Z., Khan, Z. A., Yasir, M. (2014). Analysis Of The Relationship Between CSR And Tax Avoidance: An Evidence From Pakistan. The International Journal Of Business Management, 2(7),53.

Kiabel, B. O. (2001). Personal Income Tax In Nigeria. Owerri Springfield Publisher.

Landloff. (2006). Tax Avoidance And Corporate Responsibility. International Tax Review, 6-9.

Lanis, R., \& Richardson, G. (2012). Corporate Social Responsibility And Tax Aggressivesness: A Test Of Legitimacy Theory. Journal Of Accounting, Auditing And Accounts, 26(1), 75-100.

Mardsen. (2001). The Role Of Public Authorities In Corporate Social Responsibility.

Mgbame, C.O., Chijoke-Mgbame M.A., Yekini, S., \& Yekini C.K. (2017). Corporate Social Responsibility Performance And Tax Aggressiveness. Journal Of Accounting And Taxation, 9(8), 101-108

Nadiah, H., Wan Nur Syakirah, W. K., Matora, Y., Rohayu, Y., \& Rozainum, A.A. (2017) Corporate Social Responsibility (CSR) Disclosure And Its Impacts Towards Corporate Tax Aggressiveness. Journal Of Applied And Environmental Science, 7(5S)10-15.

Octavaniana, S., Titsari, H. K., \& Chomsatu., Y.(2018). The Effect Of Profitability, Firm Size, Sales Growth And CSR Against Tax Avoidance. The 2nd International Conference On Technology Education And Social Sciences (The 2nd ICTESS 2018).

Park. S., (2017). Xorporate Social Responsibility And Tax Avoidance :Evidence From Korean Firms. Journal Of Applied Business Research, 33(6).

Putri, R. F., (2017). The Influence Of Leverage And Firm Size To Tax Avoidance (Case Study On Sub Sector Coal Company Listed On Indonesian Stock Exchange Period (2012-2016).

Rani, S., Susetyo. D., \& Faudah, L. (2018). Effects Of Corporate Characteristics On Tax Avoidance Moderated By Earnings Management (Indonesian Experience). Journal Of Accounting ,Finace And Auditing Studies, 149-169.

Sikka, P. (2010). Smoke And Mirrors: Corporate Social Responsibility And Tax Avoidance. Accounting Forum 34(3-4), 153-168.

Snider, J., Hill, R.P., \& Martin, D. (2003). Corporate Responsibility In 21st Century: A View From The World'S Most Successful Firms, 148, 175-187.

Vonwil, M., \& Wreshnoik (2009). Reputation Capital: Building And Maintaining Trust In The 21st Century, 83100.

Yuniarwati, Cenik., I.,Dewi., P.A., \& Tarumanara., C. L. (2017). Factors That Influence Tax Avoidance In The Indonesian Stock Exchange. Chinese Business Review, 10, 510-517. 